\title{
Radiation Emitted From Mobile Phone Induces Amyloidosis Features in Some Tissues of Infant Mice
}

\author{
N Hanafi*, F. Eid** and A. El-Dahshan** \\ * Radiation Biology Department, National Centre for Radiation Research and \\ Technology (NCRRT), Atomic Energy Authority (AEA), Cairo, Egypt. \\ **Zoology Department, Faculty of Science for Girls, Al-Azhar University, Cairo, \\ Egypt.
}

\begin{abstract}
Aim: Investigating the effects of mobile phone-emitted radiation (MPR) on inducing histopathological changes associated with amyloidosis feature in liver, kidney and brain of infant mice.

Methods: Twenty one infant mice (aged 1 day) were assigned to 3 groups, the $1^{\text {st }}$ group served as control, the $2^{\text {nd }}$ group exposed to mobile phone radiation ( MPR) daily for one month $\left(3 / 4 \mathrm{~h} /\right.$ day) and the $3^{\text {rd }}$ group remained for one month after stopping radiation exposure. Results: There were different degrees of damage related to amyloidosis feature in these organs subsequent to MPR exposure. One month post exposure there was an increase in the degree of damage related to amyloidosis feature.

Conclusion: the results of this study showed that MPR leads to histopathological changes associated with amyloidosis feature in the liver, kidney and brain of infant mice.
\end{abstract}

Key words: Mobile Phone, Amyloidosi, Infant Mice

\section{Introduction}

Electromagnetic field (also called electromagnetic radiation) is a region in the outer space of the Earth through which energy passes that has been created by electrically charged particles. All electromagnetic radiations come from photons. The photon energy of a cell phone is more than 10 million times weaker than the lowest energy ionizing radiation (Trottier, 2009). Studies have connected MPR to health problems such as behavioural changes, birth defects, memory loss, and Alzheimer's disease showed that mice exposed to low frequency MPR led to underdeveloped offspring's (Gabriela, 2011). Other studies on the relation between mobile phone exposure and oxidative stress tried to explain the mechanism of some determined adverse effects (Dasdag et al., 2004; Dasdag et al., 2008; Dasdag et al., 2009).

Examples of amyloid-related disorders include Alzheimer's disease (Eisele et al., 2010) and the aging process. Sobel and Davanipour (1996) hypothesized that amyloid beta (A beta) found in cerebral blood vessels, skin tissue and others were resulted post exposure to medium to high extremely low frequency (ELF) electromagnetic field (EMF). Amyloidosis is an abnormal condition whereby protein substances are deposited within the tissues of the body in the form of microscopic fibres (Westermark, 1998; Gruys, 2004). The present study was aims to the role of MPR in amyloidosis production pinpoint liver, kidney and brain tissues of infant mice.

\section{Material and Methods}

The animals were obtained from breeding animal's house of the National Centre for Radiation Research and Technology, Cairo Egypt, aged 1 day. They were maintained under controlled conditions of temperature $\left(20-25^{\circ} \mathrm{C}\right)$ and lighting (12 hours light, 12 hours dark). The experiments were approved by state authorities and followed guidelines of Egyptian law for animal protection.

Experimental animals were fed on mother's milk until weaning and then they were fed on bread, vegetables and standard rodent pellet diet with vitamins, minerals 
and were freely supplied with drinking water. Meanwhile, the amount of used food was similar in each group.

\section{Mobile phone radiation exposure}

Plastic cages (diameter $45 \mathrm{~cm}$ by $11 \mathrm{~cm}$ height) were designed for this work. The mobile phone was put inside the cages of the exposed groups. MPR was emitted from the Nokia 1112 device with a dimension of $104 \times 44 \times 17$ in connection with Egypt network (Vodafone, Egypt). The Global System for Mobile Communications (GSM) phones operates with microwave carrier frequencies in the $\mathrm{GHz}$ range $900 \mathrm{MHz}$ with $500 \mu \mathrm{W} / \mathrm{cm} 2$.

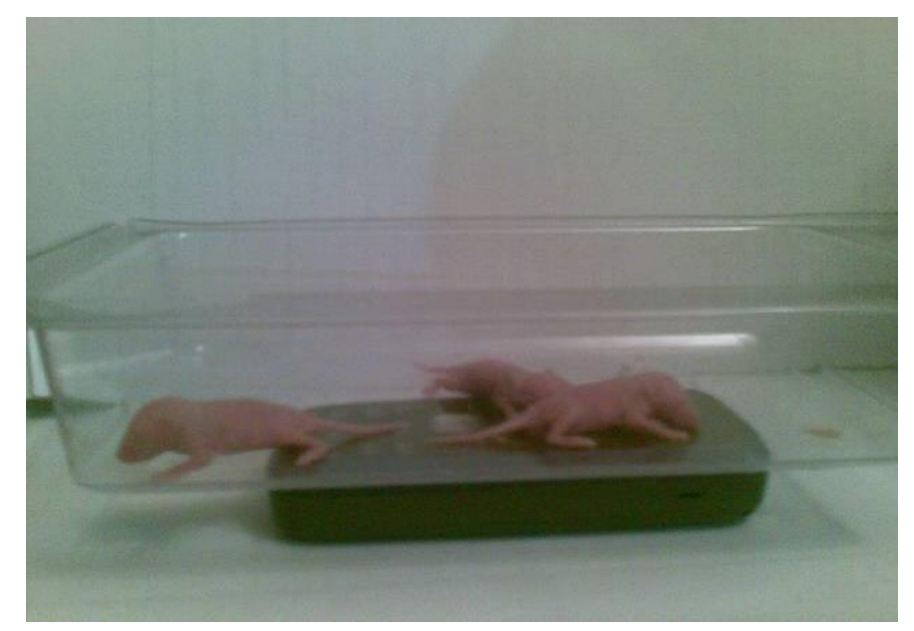

Fig. (1): Newborn mice during mobile phone exposure

\section{Experimental design}

The infant mice were classified into three equal groups (7 animals in each) one control group and two experimental groups as the following:

Group I (control): Sham-exposed infant mice were housed in the specially designed cage under experimental setup for $45 \mathrm{~min} /$ day for one month.

Group II (exposed): Infant mice were housed in the specially designed cage and exposed to MPR from mobile phone $(900 \mathrm{MHz}$ with $500 \mu \mathrm{W} / \mathrm{cm} 2$ ) for $45 \mathrm{~min} /$ day for one month.

Group III (Recovery): Newborn mice were housed in a specially designed cage and exposed to MPR as group II and then remained for one month after completion of exposure.

One day after the end of treatments the mice were anesthetized and sacrificed; brain, liver and kidney were excised, washed out from contaminating blood and fixed in $10 \%$ formaldehyde and embedded in paraffin for histopathological, histochemical and apoptotic/ necrotic detections.

\section{Histological staining.}

Sections of $5 \mu \mathrm{m}$ thickness were stained with:

- Haematoxylin and eosin (Drury and Wallington, 1980): for studying the general structure of tissue sections.

- Congo red (Sheehan and Hrapchak 1980): to demonstrate myeloid protein deposits in tissue sections.

- Mallory's trichrome stain (Mallory, 1900): For connective tissue fibrillae and reticulum detection in tissue sections.

All stains monitored under light microscope.

\section{Apoptosis and Necrosis examination}

Tissue section (2-4 $\mu \mathrm{m}$ thick) were cut from paraffin embedded blocks by microtome and mounted from warm water $\left(40^{\circ} \mathrm{C}\right)$ onto charged adhesive slides. The apoptosis and necrosis staining were analyzed using the method of Coligan et al. (1995) and Ribble et al. (2005) by using a mixture of $100 \mu \mathrm{g} / \mathrm{ml}$ acridine orange and 
Radiation Emitted......

$100 \mu \mathrm{g} / \mathrm{ml}$ ethidium bromide prepared in PBS. The tissue uptake of the stain was monitored under a fluorescence
microscope.

\section{Results}

\section{Histopathological feature of amylodosis}

\section{1-Liver}

Light microscopic observation revealed that the control hepatic tissue showed normal large polygonal cells with prominent basophilic spherical nuclei and eosinophilic cytoplasm and few spaced hepatic sinusoids arranged in-between the hepatic cords with fine arrangement of Kupffer cells (Fig. 2a, a*). In the group of infant animals exposed to MPR feature of amylodosis recorded in hepatocytes which

appeared vacuolated and contained pyknotic nuclei (Fig. 2b). After one month of MPR exposure there were features of nuclear pyknosis, karyolysis and karyorrhexis in liver sells. The hepatocytes were swollen and their cytoplasm appeared to be highly vacuolated (Fig. 2c) with mixed lymphatic monocytes infiltrations (Fig. 2d).

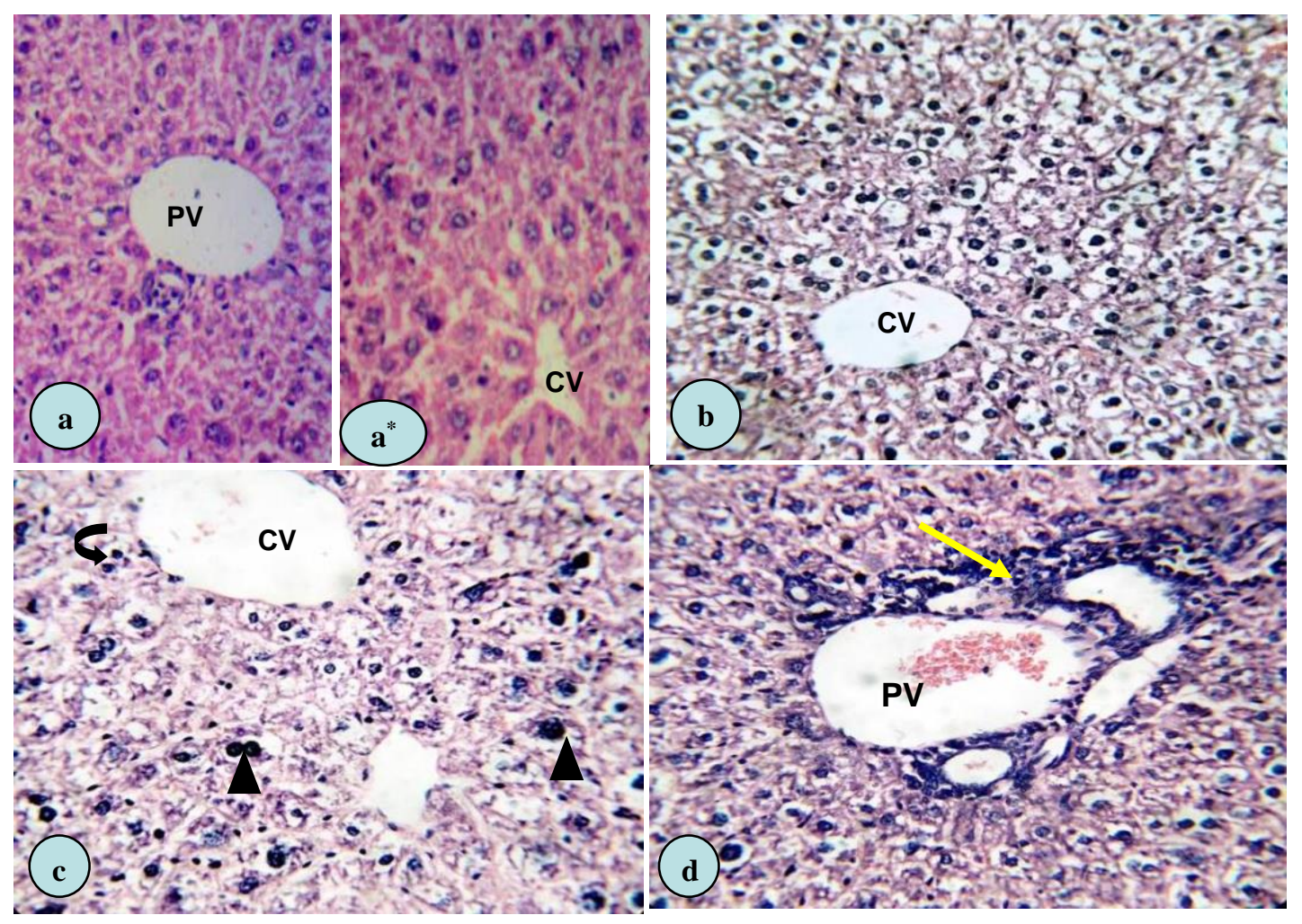

Fig. (2): Photomicrographs of sections in liver of infant mice represent a\&a*: section in control infant mouse showing normal appearance of hepatocytes portal (PV) and central vein $(\mathrm{CV})$. b: liver section from infant mouse exposed to MPR $3 / 4 \mathrm{~h} /$ day for one month shows the foamy structure of the liver hepatocytes losing their cytoplasm and presenting pyknotic nuclei. c\&d: liver of infant mouse after one month of MPR exposure end shows different feature of nuclear pyknosis, karyolysis and karyorrhexis $(\boldsymbol{\Delta})$. Lymphatic monocytes infiltrations (yellow arrow) were also recorded.

(All the figures H. and E. stain X400)

Using Mallory's trichrome stain increase in fibrotic accumulations around the portal vein after exposure to MPR $3 / 4 \mathrm{~h} /$ day for one month were observed. Meanwhile,
Congo red stain revealed deposition of amyloidal protein within hepatocytes cytoplasm after exposure to MPR 3/4 h/day for one month increased by time 


\section{N Hanafi... et al}

represents more deposition one month after stopping the exposure.

Apoptotic and necrotic stain recorded amylodosis in the form of apoptotic hepatocytes with yellow colour and others necrotic had bright orange chromatin in round nuclei after exposure to MPR 3/4 $\mathrm{h}$ /day for one month. One month after stopping the exposure amylodosis feature represented necrotic regions had bright orange chromatin in round nuclei in most of the liver cells.
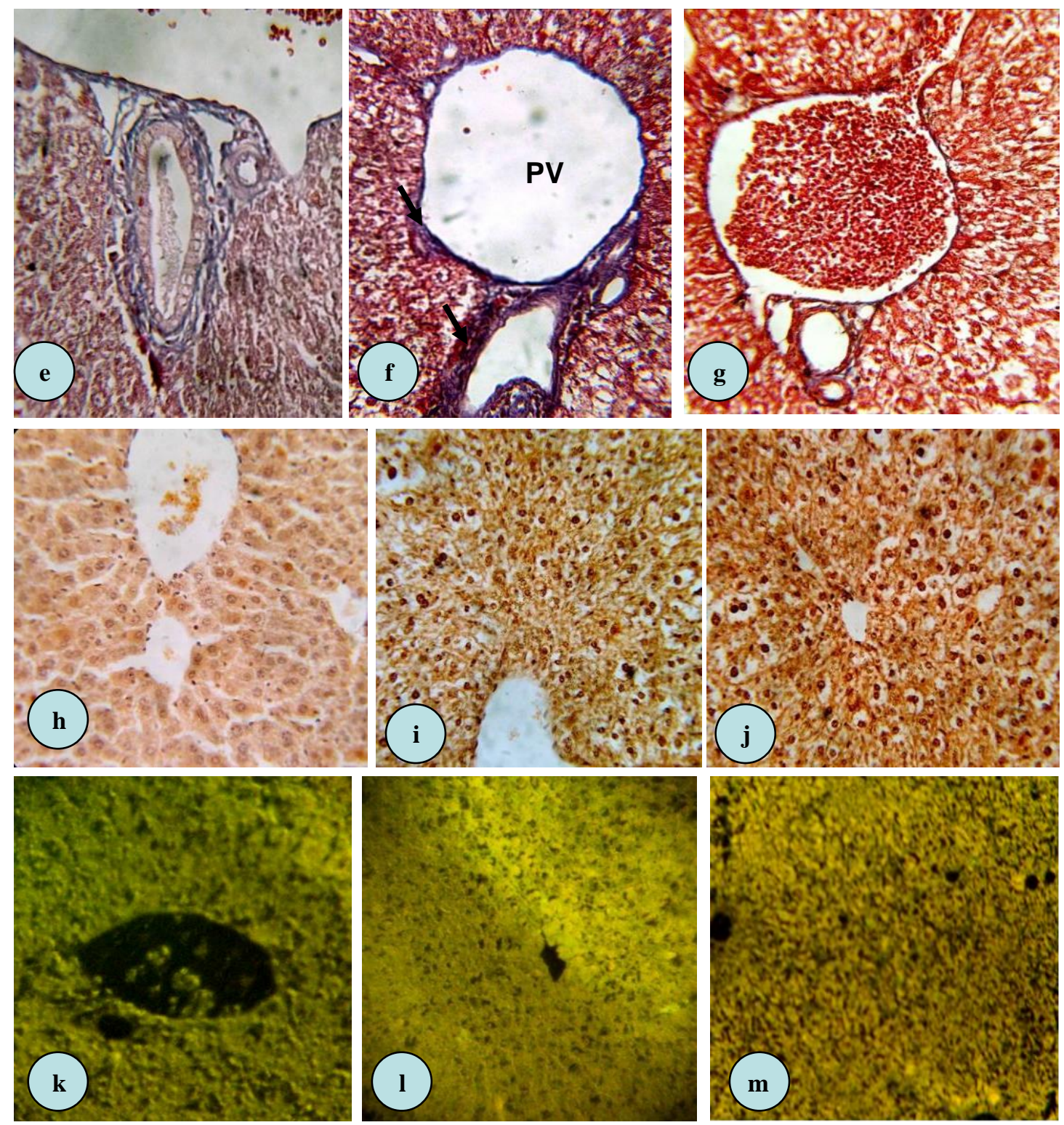

Fig. (3): Photomicrographs of sections in liver of infant mice represent $e, f$ and g: Liver section of infant mice stained with Mallory's trichrome stain showed increase in fibrotic accumulations $(\downarrow)$ around the portal vein after exposure to MPR $3 / 4 \mathrm{~h} /$ day for one month in (f). h, i and g: Liver sections of infant mice stained with Congo red show deposition of amyloid protein within hepatocytes cytoplasm after exposure to MPR $3 / 4 \mathrm{~h} /$ day for one month in (i) and more deposition was observed one month after stopping the exposure (j). k, 1 and $\mathrm{m}$ : Liver of infant mice stained with acridine orange / ethidium bromide recording apoptotic hepatocytes with yellow colour and others necrotic had bright orange chromatin in the nuclei after exposure to MPR 3/4 $\mathrm{h} /$ day for one month (l). One month after stopping the exposure most of the liver tissue sections represent necrotic regions with bright orange chromatin in the nuclei (m).

(All the figures X400) 


\section{2- Kidney}

In comparison to the control the group (Fig. 4a) kidney from infant mice exposed to MPR $3 / 4 \mathrm{~h} /$ day for one month showed atrophied glomeruli and bleeding infiltrations within convoluted tubules with the presence of obstruction of some convoluted tubules (Fig. 4b). However, kidneys of infant mice after one month of MPR exposure end bleeding was detected in between convoluted tubules (Fig. 4c).

Mallory's trichrome stain represented some fibrotic accumulations around the convoluted tubules (amylodosis feature) (Fig. 5e). Congo red recording positive amyloid protein deposition within the glomeruli and the convoluted tubules after exposure to MPR $3 / 4 \mathrm{~h} /$ day for one month (Fig. 5h). One month after stopping exposure represents more amyloid protein deposition (Fig. 5i). On the other hand, infant mice exposed to MPR $3 / 4 \mathrm{~h} /$ day for one month apoptotic and necrotic glomeruli and Mesangial cells were realized using acridine orange and ethidium bromide stain (Fig. 5k). Also, some of the convoluted tubules represented apoptotic cells (Fig. 5k). However, some recoveries were observed after one month of stopping exposure (Fig. $51)$.
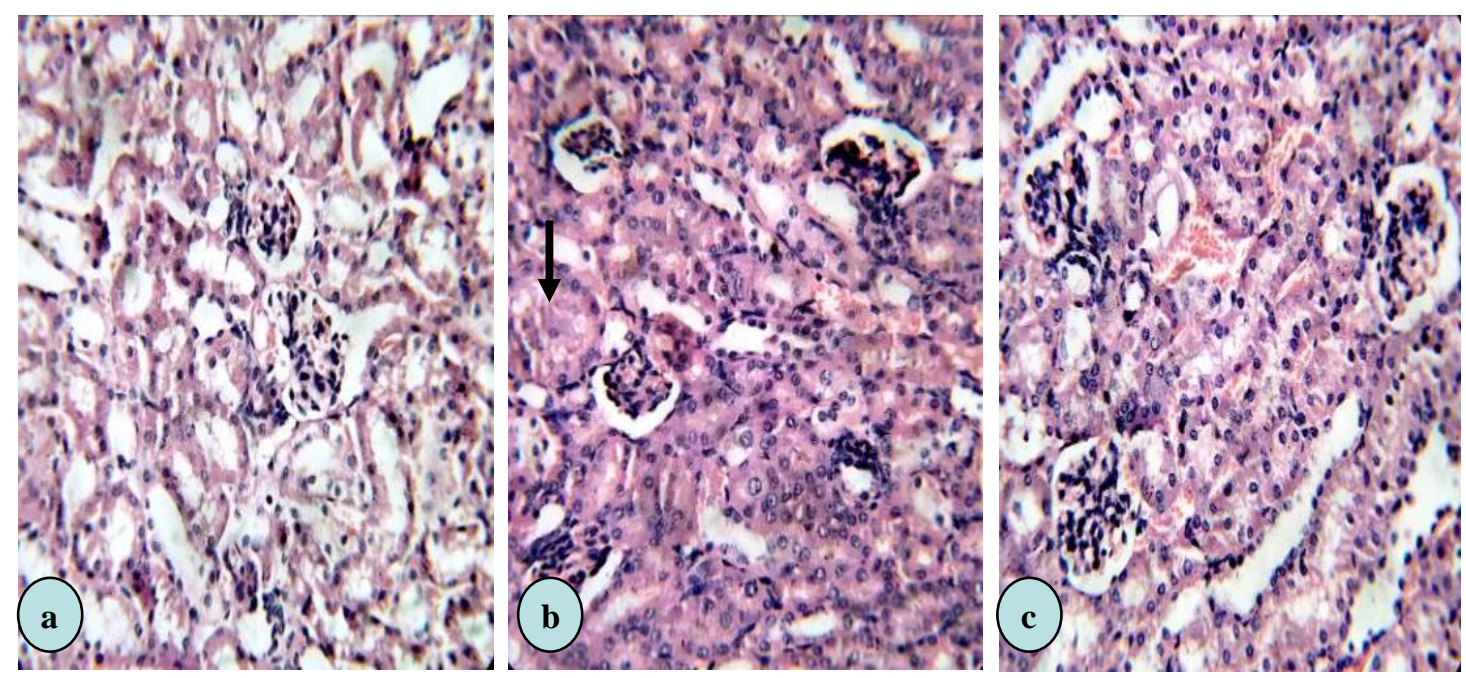

Fig. (4): Photomicrographs of sections in kidney of infant mice represent a: Section in control infant mouse shows normal appearance of glomeruli and convoluted tubules. b: Kidney section from infant mouse exposed to MPR $3 / 4 \mathrm{~h} /$ day for one month shows the compact glomeruli and bleeding infiltrations within the convoluted tubules and obstruction of some convoluted tubules $(\downarrow)$. c: Kidney section of infant mouse after one month of stopping exposure to MPR showing bleeding in between the convoluted tubules.

(All the figures H. and E. stain, X400) 

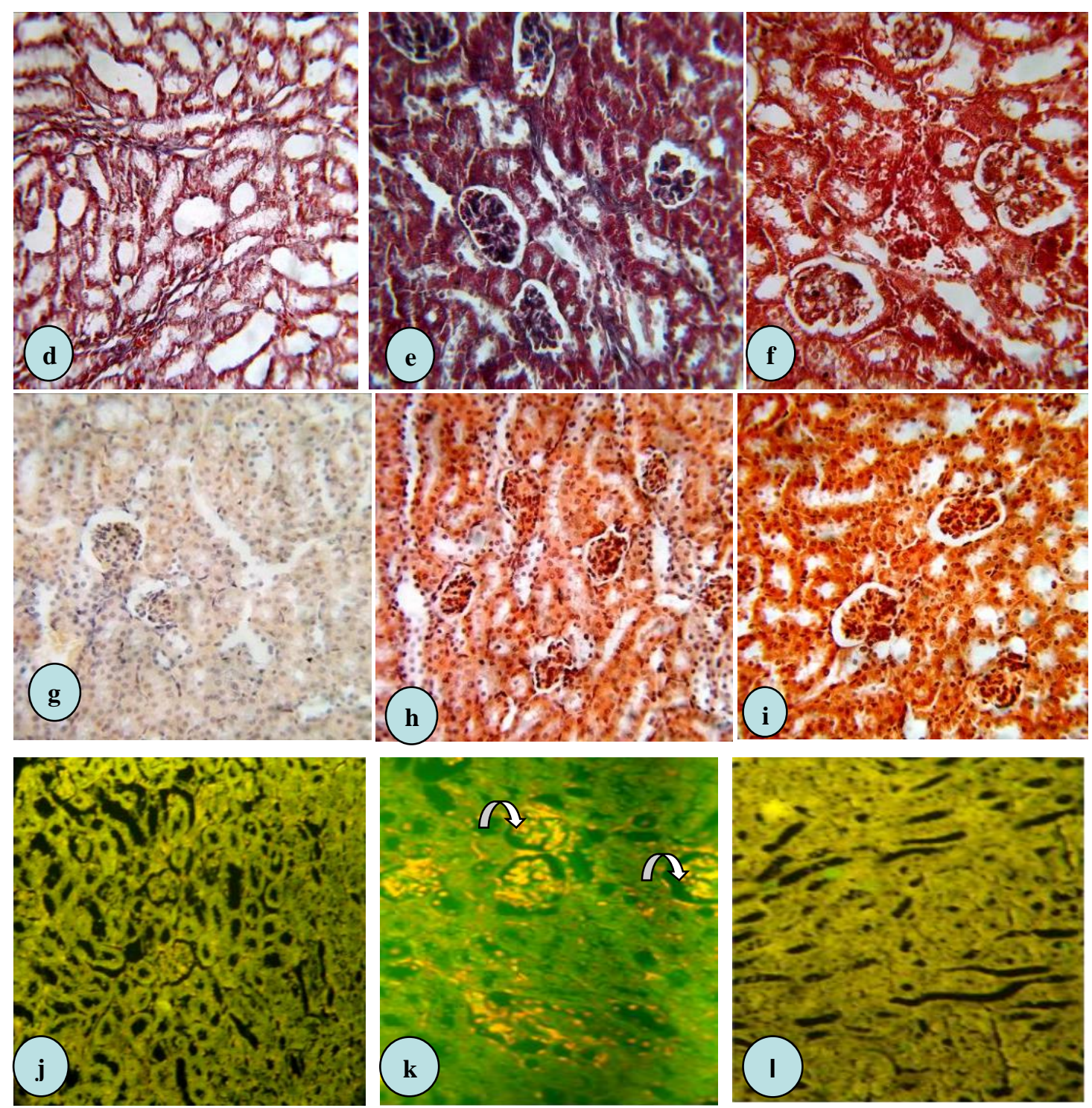

Fig. (5): Photomicrographs of sections in kidney of infant mice. All figures X400. d, e and f: kidney sections of infant mice stained by Mallory's trichrome stain show some fibrotic accumulations around the convoluted tubules after exposure to MPR 45 $\mathrm{min} /$ day for one month (e). g, h and i: kidney sections of infant mice stained with Congo red recording deposition of amyloid protein within the glomeruli and the convoluted tubules after exposure to MPR 3/4 h/day for one month (h). More deposition of amyloid protein after one month of stopping the exposure (i). j, k and l: kidney sections of infant mice stained with acridine orange/ethidium bromide represent green lived glomeruli and convoluted tubules in the control section (j). Kidney section of infant mouse exposed to MPR 3/4 h/day for one month recording apoptotic and necrotic glomerulus's Mesangial cells (curved arrow) (k). One month of stopping the exposure some recoveries were recorded (l). 


\section{Radiation Emitted......}

\section{3- Brain}

Light microscopic examination of sections of brain showed magnocellular nuclei stained with $\mathrm{H} \& \mathrm{E}$ and showed large nerve cells which were mostly multipolar or stellate in addition to pyriform cells. Astrocytes with sharply demarcated nuclei were also seen in the control cerebral cortex (Figs. 6a, a*). Exposure of the infant mice to MPR $3 / 4 \mathrm{~h} /$ day for one month represents amylodosis feature. Cerebral infarction for microglial transformation into macrophages observes in Fig. (6b). Also extensively dark pyknotic nuclei in cerebral cortex, perivascular accumulation of fluid and many zones of degenerated tissue were noticed (Figs. 6b*, b**). On the other hand cerebrum tissue of infant mice after one month of exposure to MPR represents the permanent presence of extensively dark pyknotic nuclei in brain tissue, perivascular accumulation of fluid (Fig. 6c) and the faintly eosinophilic cerebral cortex (Fig. 6c*).

Mallory's trichrome stain represents red astrocyte nuclei and pale red cerebral cortex stroma in the normal one (Fig. 7d). Increase of red colour in cerebral cortex was observed after exposure of the infant mice to MPR 3/4 h/day for one month (Fig. 7e). Cerebral cortex stroma of infant mice after one month of stopping exposure to MPR represents bluish colour recording the beginning of fibrous structure of amyloid protein deposition (Fig. 7f).

Exposure of the infant mice to MPR 3/4 $\mathrm{h} /$ day for one month represented areas of amyloid deposits, such as in amyloid plaques in cerebral cortex and a dystrophic neuron positive for amyloid Congo red stain (Fig. 7h). One month after stopping exposure to MPR, neuron positive for amyloid Congo red stain was only seen (Fig. 7i).

Acridine orange and ethidium bromide stain recording regions stained with green dye in sections of cerebellum (Fig. $7 \mathrm{j}$ ) or cerebrum tissues of control infant mice (Fig. 7j*). For amyloid protein deposition necrotic regions had bright orange chromatin in round nuclei were observed in cerebellum region (Fig. $7 \mathrm{k}$ ) and cells with yellow, condensed, or fragmented nuclei were scored as neuroapoptotic cells in cerebrum region (Fig. $7 \mathrm{k}^{*}$ ) were detected after exposure of the infant mice to MPR $3 / 4 \quad \mathrm{~h} /$ day for one month. Meanwhile, highly necrotic and apoptotic neurons were observed in cerebellum region after one month of stopping exposure to MPR (Fig. 71). 


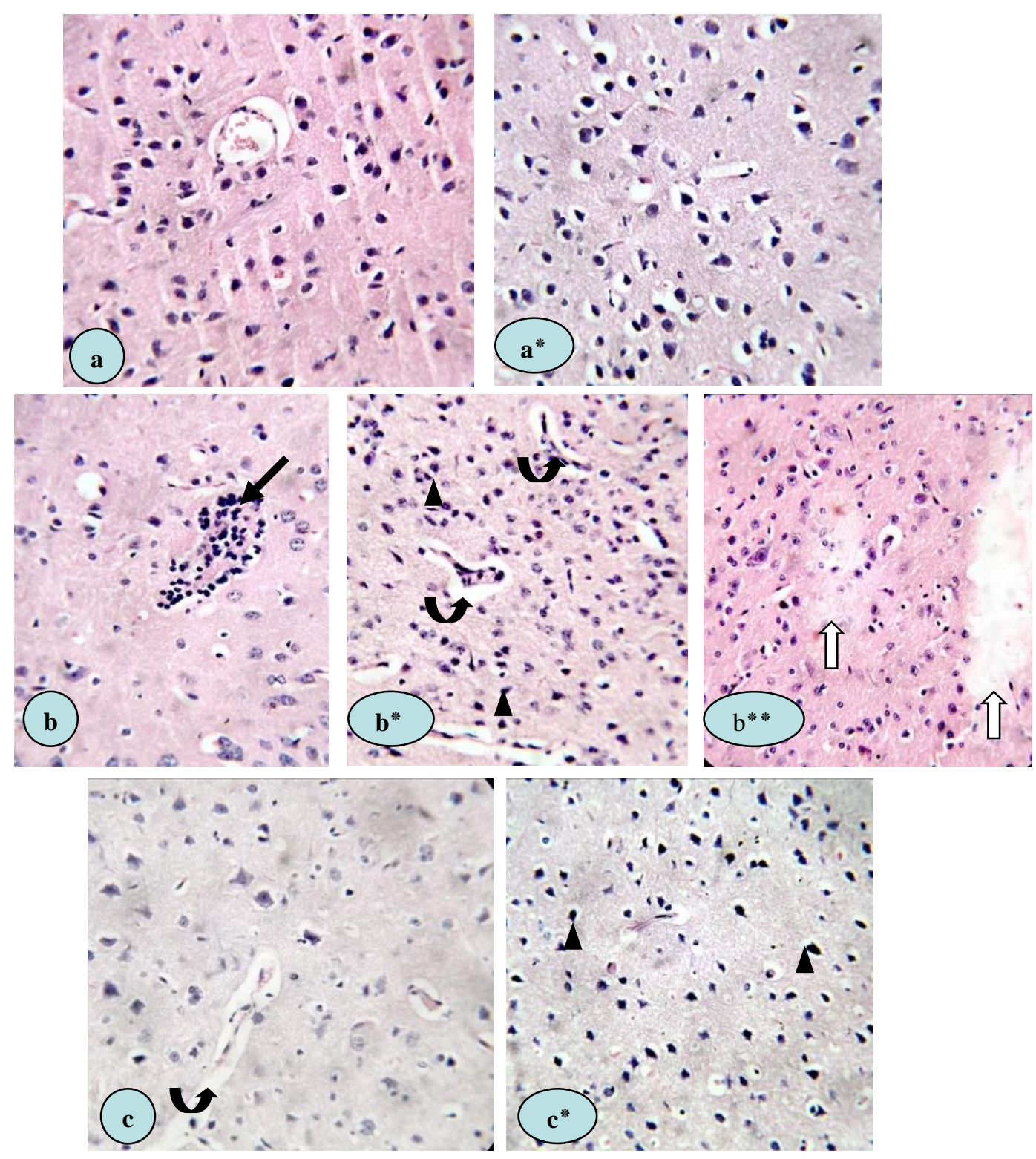

Fig. (6): Photomicrographs of sections in brain cerebral cortex of infant mice. a and a*: sections in control brain of infant mice showing normal appearance of nerve cells in brain cerebral cortex. $b, b^{*}$ and $b^{* *}$ : Brain cerebral cortex from infant mice exposed to MPR $3 / 4 \mathrm{~h} /$ day for one month represented cerebral infarction $(\uparrow)$, extensively dark pycnotic nuclei $(\boldsymbol{\Delta})$, perivascular accumulation of fluid (curved arrow) and zones of degenerated tissue (blocked arrow). $\mathrm{c}$ and $\mathrm{c}^{*}$ : Brain cerebral cortex of infant mice after one month of MPR exposure end showing presence of extensively dark pyknotic nuclei $(\boldsymbol{\Delta})$, perivascular accumulation of fluid (curved arrow) and the faintly stained eosinophilic brain cerebral cortex.

(All the figures H. and E. stain, X400) 

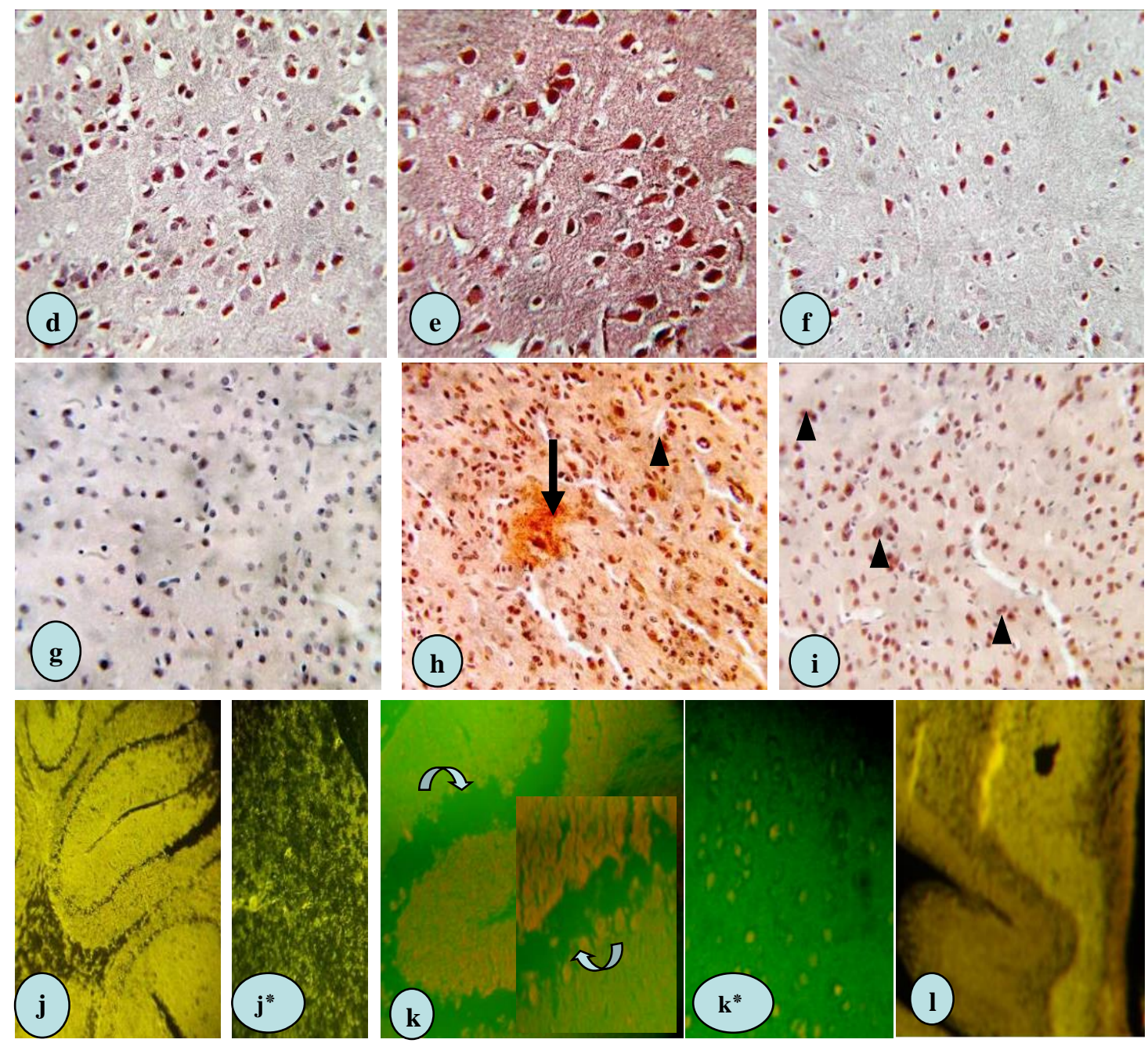

Fig. (7): Photomicrographs of section in brain of infant mice. All figures X400. d and e : brain sections of infant mice stained with Mallory's trichrome stain represented red astrocytes nuclei and pale red cerebrum tissue stroma in the normal one (d). Exposure to MPR 3/4 h/day for one month represented red colour in brain cerebral cortex (e). One month after stopping exposure represents bluish colour recording the beginning of fibrous structure (f). $\mathrm{g}, \mathrm{h}$ and i: brain sections of infant mice stained with Congo red stain. After exposure of the infant mice to MPR 3/4 h/day for one month (h) represents areas of amyloid deposits $(\downarrow)$ and a dystrophic neuron positive for amyloid Congo red stain $(\boldsymbol{\Lambda})$. One month after stopping exposure (i) records positive neurons for amyloid Congo red stain $(\boldsymbol{\Delta}) . \mathrm{j}, \mathrm{k}$ and l: brain sections of infant mice stained with acridine orange/ethidium bromide stain. Cerebellum (j) and cerebrum ( $\mathrm{j}^{*}$ ) regions stained with green dye in the control sections. Exposure of the infant mice to MPR 3/4 $\mathrm{h} /$ day for one month $\left(\mathrm{k}, \mathrm{k}^{*}\right)$ represented necrotic regions had bright orange chromatin in the nuclei of the cerebellum region (curved arrow) and neuroapoptotic cells with yellow, condensed, or fragmented nuclei in the cerebrum region. One month after stopping exposure (l) highly necrotic and apoptotic neurons were observed in the cerebellum region. 


\section{Discussion}

Exposure to electromagnetic radiation (EMR) from mobile phones can cause detrimental effects on cell function, chromosomal aberrations, and tissue injuries (Lai and Singh, 1997; Valberg et al., 1997; Moussa, 2005). A lot of studies have been carried out in relation to 900 $\mathrm{MHz}$ radiofrequency radiation (RF) emitted from mobile phone on animals tissue to investigate long term exposure to MPR on amyloid protein deposition in animals tissues (Dasdag et al., 2009). Moges, (2011) reported that amyloidosis refers to a group of protein misfolding diseases characterized by deposition of a particular amyloid protein in various organs and tissues of animals and humans. Although the fibrils are the main component of the amyloid substance we examined the histopathological effects of directs exposure to mobile phones radiations on infant Swiss albino mice.

In this study liver tissue in group of infant animals exposed for one month to MPR represented many hepatocytes with vacuolated cytoplasm and deeply stained nuclei and increase of fibrotic accumulations around the portal vein. Also, after one month of MPR exposure end liver sections showed different features of altered nuclear structure, vacuolated hepatocytes and lymphomonocytes infiltrations around the portal vein.

In this form of amyloidosis, the deposited amyloid protein is derived from serum amyloid-A synthesized in the liver (Kim et $a l$. , 2005). In this study Congo red stain recording deposition of amyloidal protein within hepatocytes cytoplasm after exposure to MPR 3/4 h/day for one month increased by time represents more deposition after one month of exposure end.

Previously similar tissue changes have been described using lower frequency EMR (Attia and Yehia, 2002; Forgács et al., 2006). Al-Glaib et al. (2008) reported that repeated exposure to the electromagnetic radiation (EMR) emitted from mobile phones is able to induce renal tissue damage. The degree of damage increased with increase the time of exposure to MPR.
Mobile phone electromagnetic radiation may be mainly absorbed by the kidney in belts form caused renal tubular injury and renal impairment in rats (Oktem et al., 2005; Ozguner and Bardak comlekci, 2006). Kidneys taken from infant mice exposed to MPR 3/4 h/day for one month represent positive deposition of amyloid protein within the glomeruli and the convoluted tubules due to Congo red stain. Amyloid protein represents more deposition after one month of stopping exposure. Although, renal amyloidosis showed symptoms of renal dysfunction due to the deposition of amyloid protein in the kidney (Hiraoka et al., 1998). Histopathologecally amylodosis feature represents as atrophied glomeruli, bleeding infiltrations within the convoluted tubules with some fibrotic accumulations around the convoluted tubules.

The present findings indicate that when infant mice exposed to MPR amylodosis feature represented apoptotic and necrotic Mesangial cells in renal glomerulus and in cells of the convoluted tubules. Also, the same observations were observed in liver hepatocytes. Hiraoka et al. (1998) reported that apoptosis played an important role in the pathogenesis of which amyloid deposition was seen in the tissue and indicated that apoptotic cells were increased in number in renal amyloidosis.

During the normal use, mobile phones emit EMFs, which are absorbed into the head and the brain of the user, thus altering and disrupt its function by interrupt the typical role of calcium in the brain (Schönborn et al., 1998; Marino et al., 2003).

In the present study light microscopic examination of sections from brain tissue of infant mice exposed to MPR $3 / 4$ h/day for one month showed the presence of cerebral infarction in which microglial cells transformed into inflammatory cells. Extensively dark pycnotic nuclei in brain cerebral cortex, perivascular accumulation of fluid and many zones of degenerated tissue illustrating the brains damage of the experimental animals (Lalancette-Hébert 
et al., 2009) and the relation between brain damage and amyloid protein deposition (Tatsuki et al., 2011).

Context with the finding of Dasdag et al. (2012), long-term exposure of $900 \mathrm{MHz}$ radiofrequency increased amyloid protein levels in the brain of rats. In this study after exposure of the infant mice to MPR $3 / 4 \mathrm{~h} /$ day for one month areas of amyloid deposits were evident as amyloid plaques in the brain tissue with a dystrophic neuron. Also, one month of MPR exposure end brain neurons represented positive amyloid deposits.

Although the main component of the myeloid substance is the fibril .Mallory's trichrome stain represented increase in red colour in brain structure after exposure of the infant mice to MPR $3 / 4 \mathrm{~h} /$ day for one month and bluish colour recording the beginning fibrous structure after one month of MPR exposure end.

Also in agreement with Sun et al. (2004) findings necrotic regions in the cerebellum and neuroapoptotic cells in cerebrum region were detected after exposure of the infant mice to MPR 3/4 h/day for one month or one month of MPR after exposure end. The overproduction of amyloid protein induced expression of the apoptosis-related Fas antigen in cultured neural, astrocytes, and microglia (Sun et al., 2004). Furthermore, amyloid protein induced nitric oxide synthetase (iNOS) and nitric oxide (NOS) production, and induced neural and glial cell apoptosis (Sun et al., 2004).

Caribaren (2011) described the theory that how MPR and electromagnetic fields (EMFs) affect cells grow and reproduce. $\mathrm{He}$ reported that each cell in the body contains positively and negatively charged elements that are kept in a delicate balance on the inside and outside of the cell wall. EMFs disorder and disrupt this critical balance, which disturbs millions of electrical impulses that the body uses to regulate cellular activity. Also, the disruption of oxidant / antioxidant balance in various tissues exposed to MPR has been shown in the experimental studies (Irmak et al., 2002; Irmak et al., 2003; Ozguner and Bardak comlekci, 2006). Laila et al. (2010) reported that the increased use of mobile phone by the public is associated with aware of contradictory reports about the possible health hazards due to the exposure of the users to electromagnetic radiation (EMR).

In conclusion, the results of this study indicated that exposure to MPR radiation could produce amylodosis features effects on the liver, kidney and brain of infant mice and these effects were increased and permanent after exposure end.

\section{References}

Al-Glaib, B., Al-Dardfi, M., Al-Tuhami, A., Elgenaidi, A. and Dkhil, M. (2008): A technical report on the effect of electromagnetic radiation from a mobile phone on mice organs. Libyan J. Med., 3 (1): 8-9.

Attia, AA. and Yehia, MA. (2002): Histological, ultrastructural and immunohistochemical studies of the low frequency electromagnetic field effect on thymus, spleen and liver of albino swiss mice. Pak. J. Biol. Sci., 5:931-937.

Caribarena News (2011): EMF effects on your body cells.http://www.caribarena.com/ antigua/ mobile/ emf-exposure.

Coligan JE, Kruisbeek AM, Margulies DH, Shevach EM and Strober W (1995): Current protocols in immunology. In: Coico R, editor. Related isolation procedures and functional assays, vol. 1. John Wiley \& Sons, Inc. 3.17.1.

Dasdag, S., Akdag, MZ., Kizil, G., Kizil. M., Cakir, DU. and Yokus, B. (2012): Effect of $900 \mathrm{MHz}$ radio frequency radiation on beta amyloid protein, protein carbonyl, and malondialdehyde in the brain. Electromagn. Biol. Med., 31(1):67-74.

Dasdag, S., Akdag, MZ., Ulukaya, E., Uzunlar, AK. and Ocak, AR. (2009): Effect of mobile phone exposure on apoptotic glial cells and status of oxidative stress in rat brain. Electromagn. Biol. and Med., 28: 342-354.

Dasdag, S., Bilgin, HM., Akdag, MZ. Celik, H. and Aksen, F. (2008): Effect of long term mobile phone exposure on oxidative antioxidative process and nitric oxide in rats. Biotechnol. Biotechnol. Eq., 22 (4): 992-997.

Dasdag, S., Akdag, MZ. and Aksen, F. (2004): Does 900 MHZ GSM Mobile Phone Exposure Affect Rat Brain? Electromagn. Biol. and Med., 23:201-214.

Drury, R. and Wallington, EA. (1980): Carlton's Histological Techniques. 5th Edn., New York Toronto Oxford University, Press 299-309.

Eisele, YS., Obermüller, U., Heilbronner, G., Baumann. F., Kaeser, SA., Wolburg, H., 
Walker. LC., Staufenbiel, M., Heikenwalder, M. and Jucker, M. (2010): Peripherally applied Abeta-containing inoculates induce cerebral beta-amyloidosis. Sci., 330(6006): 980-982.

Forgács, Z., Somosy, Z., Kubinyi, G., Bakos, J., Hudák, A., Surján, A. and Thuróczy, G. (2006): Effect of whole-body 1800MHz GSMlike microwave exposure on testicular steroidogenesis and histology in mice. Reproductive Toxicol., 22:111-117.

Gabriela, R. (2011): The natural fertility breakthrough program general resources. (2002): Effects of electromagnetic radiation from a cellular telephone on the oxidant and antioxidant levels in rabbits cell. Biochem. Funct., 20(4): 279-283.

Irmak, MK., Ozatos, E., yagmurca, M., Fadillioglu, E. and Bakir, B. (2003): Effects of electromagnetic radiation from a cellular phone on epidermal Merkel cells. J. Cutan. Pathol., 30: 135-138.

Kim, DY., Taylor, HW., Eades, SC. and Cho, DY. (2005): Systemic AL amyloidosis associated with multiple myeloma in a horse. Vet. Pathol., 42:81-84.

Lai, H. and Singh, NP. (1997): Acute exposure to a $60 \mathrm{~Hz}$ Magnetic field increase DNA strand breaks in rat brain cells. Bioelectromagnetics, 18:156-165.

Laila, KH., Sawsan, HK. and Anisa, S. (2010): The adverse effects of mobile phone radiation on some visceral organs. Res. J. of Med. and Medic. Sci., 5(1): 95-99.

Lalancette-Hébert, M., Phaneuf,D., Soucy, G., Weng, YC. and Kriz, J. (2009): Live imaging of Toll-like receptor 2 response in cerebral ischaemia reveals a role of olfactory bulb microglia as modulators of inflammation. Brain, 132: 940-954

Mallory, FB. (1900): A contribution to staining methods: I. A differential stain for connective-tissue fibrillae and reticulum. II. Chloride of iron haematoxylin for nuclei and fibrin. III. Phosphotungstic acid haematoxylin for neuroglia fibres. J. Exp. Med., 15-20.

Marino, A., Nilsen, E. and Frilo, C. (2003): Nonlinear changes in brain electrical activity due to cell phone radiation. Bioelectromagnetics, 24: 339.

Moges, W. (2011): 8 Amyloidosis in Domestic Animals: Pathology, Pathogenesis, Gross and Microscopic Lesions and Clinical Findings. In Tech, 149-162.

Moussa, EA. (2005): Effect of electromagnetic field on liver and kidney tissues of Swiss albino mice. J. Egypt. Ger. Soc. Zool, 48:29-53.

Oktem, F., Ozguner, F., Mollaoglu, H., Koyu, A. and Uz, E. (2005): Oxidative damage in the kidney induced by $900 \mathrm{MHz}-$
Fertility Specialist \& Naturopath MScM (RHHG) (Cand.), 1:11.

Gruys, E. (2004): Protein folding pathology in domestic animals: A review. J.of Zhejiang Uni. Sci., 5(10):1226-1238.

Hiraoka, J., Asano, K., Sano, H., Fujisawa, K., Ohno, M., Takemura, G., Minatoguchi, S., Ohashi, H., Fujiwara, T. and Fujiwara, H. (1998): Participation of apoptosis in renal amyloidosis. Nihon Jinzo Gakkai Shi., 40(4):276-283.

Irmak, MK., Fadillioğlu, E., Güleç, M., Erdoğan, H., Yağmurca, M. and Akyol, O. emitted mobile phone: Protection by melatonin. Arch. Med. Res., 36: 350-355.

Ozguner, F. and Bardak comlekci, Y. (2006): Protective effects of melatonin and caffeic acid phenethyle ester against retrial oxidative stress in long term use of mobile phone: a comparative study. Mel. Cell Biochem., 282: 83-88.

Ribble, D., Goldstein, NB., Norris, DA. and Shellman, YG. (2005): A simple technique for quantifying apoptosis in 96-well plates. BMC Biotechnol., 10: 5-12.

Schönborn F, Burkhardt $M$ and Kuster N (1998): Differences in energy absorption between heads of adults and children in the near field of sources. Health Phys., 74: 160.

Sheehan, D. and Hrapchak, B. (1980): Theory and practice of Histotechnology $2^{\text {nd }}$ Edn pp: 175-178, Battelle Press, Ohio.

Sobel, E. and Davanipour, Z. (1996): Electromagnetic field exposure may cause increased production of amyloid beta and eventually lead to Alzheimer's disease. Neurology, 47(6): 1594-1600.

Sun, KH., Sun, GH., Su, Y., Chang, CI., Chuang, MJ., Wu, WL., Chu, CY. and Tang, SJ. (2004) : Acidic-rich region of amyloid precursor protein induces glial cell apoptosis. Apoptosis, 9 (6): 833-841.

Tatsuki, I., Motohiro, I., Shozo, N., Masahiro, T., Shigeo, H., Akihiko, I. and Takao, S. (2011): Expression and cerebral function of amyloid precursor protein after rat traumatic brain injury. InTech, alzheimer's disease pathogenesis-core concepts, shifting paradigms and therapeutic targets, 3: 31-52.

Trottier L (2009): "EMF and health: A Growing Hysteria. Skeptical Inquirer. September/October.

Valberg PA, Kavet $R$ and Rafferty $C N$ (1997): Can low level 50"M60 HZ electric and magnetic field cause biological effects. Radiat. Res., 148: 2-12.

Westermark P (1998): The pathogenesis of amyloidosis. Understanding general principles. American J. Pathol., 152(5):1125-1127. 


\title{
الإشعاع المنبعث من الهاتف المحمول يسبب تغيرات هنتوباثولوجية وتكوين أميلويدات فى أنسجة الفئران الرضع تصنير
}

\author{
نعمات حنفى ـ فاطمة عبد ـ أسماء الدهشان
}

الههف : الكثف عن تأثثر الإشعاعات المنبعثة من الهاتف المحمول فى إحداث تغير ات نسيجيه مرضية

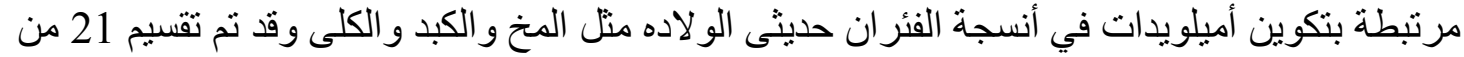

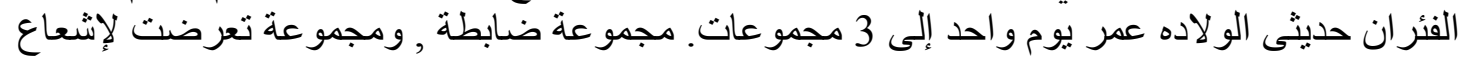

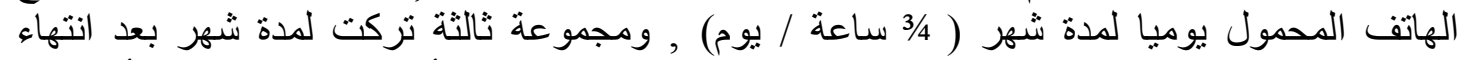

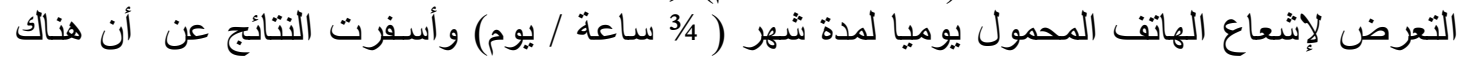

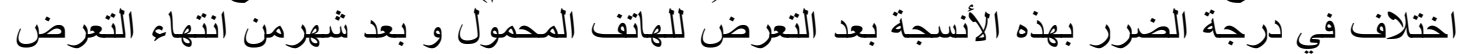
لإشعاع الهاتف ز ادت درجة الضردة الضرر بهذه الأنسجة.

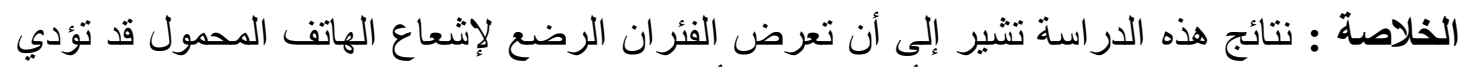

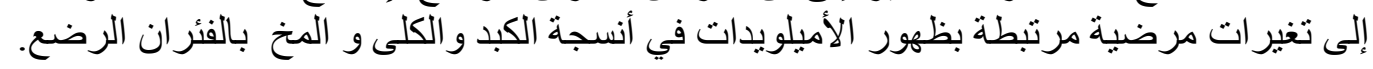

